\title{
Airborne Benzo[a]Pyrene may contribute to divergent Pheno-Endotypes in children
}

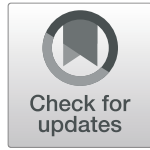

Hyunok Choi ${ }^{1 *} \mathbb{D}$, Miroslav Dostal ${ }^{2}$, Anna Pastorkova², Pavel Rossner $\mathrm{Jr}^{2}$ and Radim J. Sram²

\begin{abstract}
Background: Asthma represents a syndrome for which our understanding of the molecular processes underlying discrete sub-diseases (i.e., endotypes), beyond atopic asthma, is limited. The public health needs to characterize etiology-associated endotype risks is becoming urgent. In particular, the roles of polyaromatic hydrocarbon (PAH), globally distributed combustion by-products, toward the two known endotypes - Thelper 2 cell high (Th2) or T helper 2 cell low (non-Th2) - warrants clarification.

Objectives: To explain ambient B[a]P association with non-atopic asthma (i.e., a proxy of non-Th2 endotype) is markedly different from that with atopic asthma (i.e., a proxy for Th2-high endotype).

Methods: In a case-control study, we compare the non-atopic as well as atopic asthmatic boys and girls against their respective controls in terms of the ambient Benzo[a]pyrene concentration nearest to their home, plasma 15$\mathrm{F}_{\mathrm{t2} 2}$-isoprostane (15- $\mathrm{F}_{\mathrm{t2}}$-isoP), urinary 8-oxo-7,8-dihydro-2'-deoxyguanosine (8-oxodG), and lung function deficit. We repeated the analysis for i) dichotomous asthma outcome and ii) multinomial asthma—overweight/obese (OV/OB) combined outcomes.

Results: The non-atopic asthma cases are associated with a significantly higher median B[a]P $\left(11.16 \mathrm{ng} / \mathrm{m}^{3}\right)$ compared to that in the non-atopic controls $\left(3.83 \mathrm{ng} / \mathrm{m}^{3} ; P\right.$-value $\left.<0.001\right)$. In asthma-OV/OB stratified analysis, the non-atopic girls with lean and OV/OB asthma are associated with a step-wisely elevated B[a]P (median,11.16 and $18.00 \mathrm{ng} / \mathrm{m}^{3}$, respectively), compared to the non-atopic lean control girls (median, $4.28 \mathrm{ng} / \mathrm{m}^{3}, P$-value $<0.001)$. In contrast, atopic asthmatic children $\left(2.73 \mathrm{ng} / \mathrm{m}^{3}\right)$ are not associated with a significantly elevated median $\mathrm{B}[\mathrm{a}] \mathrm{P}$, compared to the atopic control children $\left(2.60 \mathrm{ng} / \mathrm{m}^{3} ; P\right.$-value $\left.>0.05\right)$. Based on the logistic regression model, on In-unit increate in $\mathrm{B}[a] \mathrm{P}$ is associated with 4.7-times greater odds $(95 \% \mathrm{Cl}, 1.9-11.5$, $P=0.001)$ of asthma among the non-atopic boys. The same unit increase in $\mathrm{B}[a] \mathrm{P}$ is associated with 44.8times greater odds $(95 \% \mathrm{Cl}, 4.7-428.2, P=0.001)$ among the non-atopic girls after adjusting for urinary Cotinine, lung function deficit, $15-\mathrm{F}_{\mathrm{t} 2}$-isoP, and 8-oxodG.
\end{abstract}

Conclusions: Ambient $\mathrm{B}[a] \mathrm{P}$ is robustly associated with non-atopic asthma, while it has no clear associations with atopic asthma among lean children. Furthermore, lung function deficit, 15- $\mathrm{F}_{\mathrm{t} 2}$-isoP, and 8-oxodG are associated with profound alteration of $\mathrm{B}[a] \mathrm{P}$-asthma associations among the non-atopic children.

Keywords: Air pollution, Benzo[a]pyrene, Endotype;15- $\mathrm{F}_{\mathrm{t2}}$-isoprostane, 8-oxo-7,8-dihydro-2'-deoxyguanosine

\footnotetext{
* Correspondence: hyc219@lehigh.edu

${ }^{1}$ College of Health, Lehigh University, Bethlehem, PA, USA

Full list of author information is available at the end of the article
}

(C) The Author(s). 2021 Open Access This article is licensed under a Creative Commons Attribution 4.0 International License, which permits use, sharing, adaptation, distribution and reproduction in any medium or format, as long as you give appropriate credit to the original author(s) and the source, provide a link to the Creative Commons licence, and indicate if changes were made. The images or other third party material in this article are included in the article's Creative Commons. licence, unless indicated otherwise in a credit line to the material. If material is not included in the article's Creative Commons licence and your intended use is not permitted by statutory regulation or exceeds the permitted use, you will need to obtain permission directly from the copyright holder. To view a copy of this licence, visit http://creativecommons.org/licenses/by/4.0/. The Creative Commons Public Domain Dedication waiver (http://creativecommons.org/publicdomain/zero/1.0/) applies to the data made available in this article, unless otherwise stated in a credit line to the data. 


\section{Introduction}

Asthma represents the most common respiratory impairment worldwide, afflicting over 400 million people of all age groups, racial/ethnic backgrounds, and genders $[1,2]$. The asthma burden is growing despite the introduction of therapeutic strategies, pharmacologic interventions, and other public health measures [2]. Asthma has come to be recognized as an umbrella term for multiple subtypes of diseases, originating from distinct mechanisms (i.e., endotype) [3-6]. However, in practice, asthma is still diagnosed based on observable clinical characteristics (i.e., phenotypes) [7]. Such 'once-size-fitsall' detection and management strategies, focused on symptom easement without considering the etiologic mechanisms, are thought to contribute to the burgeoning economic burden of asthma, particularly by those with poorly controlled subtypes [8]. Furthermore, nearly $50 \%$ of the poorly-controlled asthmatic children are expected to emerge as severe adult cases [9]. There is a growing call to diversify the asthma subtypes beyond allergic asthma, based on the cellular and molecular mechanistic origins [9]. Mechanism-based definitions of asthma could help identify early effect biomarkers for specific sub-types [7]. The development of such biomarker-based therapies in asthmatic children before the onset of irreversible respiratory injuries represents an urgent public health need $[9,10]$.

Asthma is presently distinguished in terms of two major endotypes, $\mathrm{T}$ helper 2 cell high (Th2-high) and $\mathrm{T}$ helper 2 cell low (non-Th2) [3, 5]. However, diagnostic criteria of Th- 2 high and non-Th2 endotypes are both evolving and putative [10]. The Th2-high endotype is associated with clinical features such as early-onset atopy, IgE production, and eosinophilic inflammation [3]. Th2-high endotype is believed to be made up of at least three subtypes, early-onset atopic [11], late-onset eosinophilic, and aspirin-exacerbated respiratory disease (AERD) [10]. In contrast, the non-Th2 endotype is even less understood in terms of its mechanistic origin and progression, even though it is estimated to comprise about half of all asthma cases [12, 13]. The salient features of the non-Th2 endotype are that the sufferers are typically non-atopic, women, overweight/obese, or do not respond well to corticosteroid therapy [10]. It has also been associated with cigarette smoke exposure [10]. Another notable characteristic of the non-Th2 endotype is that oxidative stress likely mediates (i) initiation of the IL-17- pathways and (ii) dysregulation of innate immune cells, ultimately resulting in neutrophil activation [14].

To date, it remains unknown whether fossil-fuel combustion-based air pollution $[15,16]$, in particular, polyaromatic hydrocarbon (PAH), globally distributed combustion by-products contribute toward either Th2 or non-Th2 endotypes. In our earlier investigation, we have shown that childhood exposure to ambient Benzo[a]pyrene $(\mathrm{B}[a] \mathrm{P})$ is significantly associated with clinically diagnosed asthma in children [17-23]. In particular, ambient $\mathrm{B}[a] \mathrm{P}$ exposure was associated with the largest increase in odds of asthma among the overweight/obese $(\mathrm{OV} / \mathrm{OB})$ children in a sexually dimorphic fashion [18]. However, we did not directly examine whether airborne $\mathrm{PAH}$ poses a greater risk on $\mathrm{OV} / \mathrm{OB}$ girls via the non-Th2 endotype.

Here, we consider a collection of phenotypes (e.g., non-atopic and atopic asthma), clinical characteristics (e.g., sex, OV/OB status), biomarkers of molecular mechanisms (e.g., systemic oxidant burden), and natural history (e.g., lung function impairment) to contrast $\mathrm{B}[a] \mathrm{P}$ association with non-atopic and atopic asthma cases, respectively. Specifically, we test a novel hypothesis that ambient $\mathrm{B}[a] \mathrm{P}$ association with non-atopic asthma (i.e., a proxy of non-Th2 endotype) is markedly different from its association with atopic asthma (i.e., a proxy for Th2-high endotype). To distinguish the mechanistic insights underlying non-atopic and atopic asthma (i.e., phenotypes), we investigate the above hypothesis using three sub-hypotheses. First, we postulate that the $\mathrm{B}[a] \mathrm{P}$-asthma association is significantly different for the non-atopic children than the atopic children. Second, we posit that systemic oxidant burden (i.e., plasma $15-\mathrm{F}_{\mathrm{t} 2}-$ isoprostane (abbreviated as $15-\mathrm{F}_{\mathrm{t} 2}$-isoP) and urinary 8oxo-7,8-dihydro-2'-deoxyguanosine (abbreviated as 8oxodG)) and lung function deficit, as two respective biomarkers of endotype developments, play divergent roles in non-atopic vs. atopic asthma per unit increase in $\mathrm{B}[a] \mathrm{P}$ exposure. Third, considering our earlier observations [18], we posit that asthma-BMI combined outcomes (i.e., OV/OB Control, Lean Asthmatic, and OV/ $\mathrm{OB}$ Asthmatic) represent phenotypic spectra nested within the respective endotypes, compared to Lean Controls, the reference group. Thus, $\mathrm{B}[a] \mathrm{P}$ association with the non-atopic OV/OB asthmatic girls are different from the $\mathrm{B}[a] \mathrm{P}$ association with atopic $\mathrm{OV} /$ $\mathrm{OB}$ asthmatic girls.

\section{Material and methods}

The study population's socioeconomic traits, exposure sources, and overall approaches are described [18, 20, 23]. Briefly, a case-control study was conducted on 191 asthmatics and 194 control children in November 2008. Children were enrolled from an industrial city, Ostrava ( $n=94$ asthmatic and 96 controls), and semi-rural villages across the Southern Bohemia ( $n=97$ asthmatic and 98 controls) in the Czech Republic [24]. The children's medical record, questionnaire data (filled out by the parents and the child's primary care doctor), and informed consent are obtained. The children also provided blood and urine samples. The institutional review 
board at the Institute of Experimental Medicine, Academy of Science, Czech Republic, reviewed and approved the study.

\section{Study sites}

A comparable number of case $(n=191)$ and control $(n=$ 194) children were enrolled from case-control children were enrolled from an industrial city (i.e., Ostrava) and background towns (i.e., Southern Bohemia) in the Czech Republic [24]. Ostrava is a historically industrial city with a high level of coal mining activities, coal processing, and metallurgical refinement. The most polluted districts (i.e., Radvanice/Bartovice) within Ostrava was chosen as the target enrollment region. The district-level ambient mean $\left(11.4 \mathrm{ng} / \mathrm{m}^{3}\right)$ for $\mathrm{B}[a] \mathrm{P}$ during our investigation period (November 2008) was approximately 11-times higher than the recommended ambient and indoor air quality standard $\left(1 \mathrm{ng} / \mathrm{m}^{3}\right)$ [25]. The mean outdoor $\mathrm{B}[a] \mathrm{P}$ in our background region during the same period is $2.5 \mathrm{ng} / \mathrm{m}^{3}$. Known airborne $\mathrm{B}[\mathrm{a}] \mathrm{P}$ emission sources in the background region consist of residential heating and automobile exhaust [23].

\section{Air pollution monitoring of polycyclic aromatic hydrocarbons}

Publicly available ambient concentration of Benzo[a]Pyrene $(\mathrm{B}[a] \mathrm{P})$ is downloaded from the Czech Hydrometeorological Institute for November 2008 [26]. Eight particle-bound PAHs are routinely monitored using Versatile Air Pollution Sampler [23, 27, 28]. CHMI manages and monitors eight airborne particle-bound PAHs and $\mathrm{PM}_{2.5}$ using Versatile Air Pollution Sampler (VAPS) since the 1990s [26]. Particle-bound PAHs are extracted from filters, and quantitative chemical analysis of PAHs was performed by high-performance liquid chromatography (HPLC) with fluorescence detection according to the US Environmental Protection Agency (EPA) method [26]. Based on the CHMI protocol, the mean daily level is measured once every three days for ten days/month in southern Bohemia; once every six days for five days/ month in Ostrava. Additional details on quality assurance and control have been described [23, 27, 28].

\section{5-F2t-IsoP immunoassay}

Plasma concentrations of 15-F2t-IsoP are analyzed using immunoassay kits as described [29].

\section{Urinary 8-oxodG}

The concentration of urinary 8-oxodG, using competitive ELISA, is performed [30]. Children's urine sample are incubated with $50 \mu \mathrm{l}$ of 8 -oxo-dG standards (concentration range, $1.25-40 \mathrm{ng} / \mathrm{ml}$ ), $50 \mu \mathrm{l}$ of primary antibody (JaICA, Japan, clone N45.1, concentration $0.2 \mu \mathrm{g} / \mathrm{ml}$ ) as well as $100 \mu \mathrm{l}$ of secondary antibody conjugated with alkaline phosphatase. Any samples, which demonstrated inhibition $<20 \%$ or $>$ $80 \%$ are repeatedly analyzed with or without additional dilution. Urinary 8-oxo-dG concentration is determined as nmol 8 -oxo- $\mathrm{dG} / \mathrm{mmol}$ creatinine.

\section{Asthma diagnosis}

The diagnosis is made during multiple clinic visits, based on the child's clinical symptoms, laboratory markers, and by performing lung function test, bronchodilation test, and skin prick tests on older children. The children's designated primary care physician used a different set of clinical criteria for the older children ( $\geq 5$ years in age) vs. infants and toddlers ( $\leq 4$ years in age). In children 5 years in age or older, a positive diagnosis of asthma is made if the child had three or more of the following events, including the parental report of $\geq 2$ episodes of cough (any time during the day); chest tightness and/or belabored breathing; wheezing and/or whistling sound during breathing; school absence or limitation in play activities; emergency room visit and/or hospitalization from acute symptom exacerbation. A skin prick test is given to each child to determine the allergen sensitization status (i.e., wheal size $\geq 3 \mathrm{~mm}$ diameter) following an application of common local allergen on the volar arm (PhadiatopH, Pharmacia \& Upjohn Diagnostics, Uppsala, Sweden). On children $\leq$ four years in age, the following primary and secondary criteria are considered. Major criteria include i) history of hospitalization for bronchiolitis or heavy wheezing dyspnea; ii) a minimum of three wheezing dyspnea episodes within the last six months; iii) positive asthma diagnosis in either parent, and iv) atopic dermatitis diagnosis. Minor criteria include i) atopic rhinitis diagnosis without an indication of infection; ii) history of wheezing without an indication of infection; iii) Eosinophilia; and iv) male sex. If the infant/ toddler met at least one primary and at least two secondary criteria, he/she is considered to be at high risk of asthma. Such children are closely monitored.

On the other hand, asymptomatic controls included those who are free from all symptoms. For each new asthma case we identified, we recruited one control child who matches the case in terms of the geographic district, age range, and gender. All children were given a lung function test at the clinic following the American Thoracic Society and the European Respiratory Society guidelines [31]. The children who were positive for lung function deficit was defined as those with lower than expected FVC $(<85 \%$ of predicted based on age, sex, height, and weight for Czech children), lower than expected FEV1 $(<85 \%$ predicted), lower than expected PEF $(<75 \%$ predicted), or maximal mid-expiratory flow $(<75 \%$ predicted $)$. 


\section{Cotinine assays}

Urinary concentration of creatinine-adjusted Cotinine concentration is measured using a spectrophotometric method [32], followed by radioimmunoassay [33]. A cutoff value of $>450 \mathrm{ng} / \mathrm{mg}$ and $20-449 \mathrm{ng} / \mathrm{mg}$ are used to define active and passive smokers, respectively [34].

\section{Statistical analysis}

All of our analyses are stratified according to atopy status and gender to clarify the modification of $\mathrm{B}[a] \mathrm{P}$ effects on asthma. We restricted the present analysis to those with low to no recent exposure to cigarette smoke (Cotinine $<20 \mathrm{ng} / \mathrm{mg}$ ) by removing all active smoking (> $450 \mathrm{ng}$ cotinine/mg creatinine) or passive smokers (20-449 ng/mg).

\section{Exposure window of interest}

Ambient $\mathrm{B}[a] \mathrm{P}$ concentration at a monitor nearest to each child's home was used as a proxy for his/her exposure. Consistent with our earlier analysis, we defined optimal exposure window as an average for 30-day periods during November 2008 [28, 35]. To better understand the representativeness of present exposure (during November 2008) for exposure during earlier childhood, we compared the median and interquartile ranges of the 30-day average for November 2008 against those from November 2007 and November 2006, respectively. The 30-day average concentration of November 2008 was consistent with the 30-day average concentrations from the earlier years.

\section{Primary health outcomes of interest}

As described earlier, each child was categorized into the lean, overweight, or obese category if their body mass index (BMI, weight $/$ height $^{2}$ ) fell within the expected range for European children at a given age and sex [36]. The overweight and obese were combined into a single category (and henceforth termed OV/OB) due to low count. We considered either asthma outcome alone (yes/no) or asthma diagnosis (yes/no) with OV/OB status (yes/no) combined outcome (with four categories). Set against the lean controls (i.e., the reference group), those with $\mathrm{OV} / \mathrm{OB}$ outcome alone without asthma (i.e., $\mathrm{OV} / \mathrm{OB}$ control), lean asthmatics without $\mathrm{OV} / \mathrm{OB}$ (i.e., lean asthma), and the children with both $\mathrm{OV} / \mathrm{OB}$ and asthma (i.e., OV/OB asthma) are set as three nominal outcome groups.

\section{Identification of confounders}

In our earlier analysis, we examined potential confounding of $\mathrm{B}[a] \mathrm{P}$-asthma association by age, gender, Cotinine, the total number of smokers in the family, maternal smoking at home, body mass index, plasma levels of Vitamin $\mathrm{C}, \mathrm{A}$, and $\mathrm{E}(\mathrm{mg} / \mathrm{L})$, the season of delivery (indicator variables, fall, winter, and spring), birth weight and gestational age at delivery. Either Pearson $x^{2}$ test or Spearman's ranked agreement coefficient $(\delta)$ was used to consider the univariate association between each of the above variables with either ambient $\mathrm{B}[a] \mathrm{P}$ or the asthma outcome, respectively [23]. The median and the interquartile range of the primary exposure and other covariates are compared across the outcome groups, using Jonkheere-Terpestra (JT) test with $\alpha=0.05$.

\section{Model building}

Parsimonious multinomial logistic regression models per one (ln)-unit increase in $\mathrm{B}[a] \mathrm{P}$ are built by forward-selecting putative confounders, including $\mathrm{Co}$ tinine alone; cotinine and lung function deficit; Cotinine, lung function deficit, and $15-\mathrm{F}_{2 \mathrm{t}}$-IsoP; or by adjusting for Cotinine, lung function deficit, $15-\mathrm{F}_{2 \mathrm{t}^{-}}$ IsoP as well as 8-oxo-7,8-dihydro-2'-deoxyguanosine (8-oxodG) (Table 3 and S1-S4). Due to the high correlation with the plasma concentration of 15-F2t-IsoP, Carbonyl's plasma concentration is not included in the final model as a covariate. Our regression diagnostics carefully examined the robustness of the estimated odds ratios following the removal of an influential variable. All analyses were performed with SPSS version 20.0.1 for Windows (SPSS Inc., Chicago, Illinois, USA).

\section{Results}

A descriptive comparison of non-atopic vs. atopic asthma cases and controls

Table 1 summarizes the demographic, exposures, and natural histories of non-atopic and atopic asthma cases, compared to their respective controls. The non-atopic asthma cases are associated with a significantly higher median $\mathrm{B}[a] \mathrm{P}\left(11.16 \mathrm{ng} / \mathrm{m}^{3}\right)$ compared to that in the non-atopic controls $\left(3.83 \mathrm{ng} / \mathrm{m}^{3}\right.$; JT $P$-value $\left.<0.001\right)$. In contrast, atopic asthmatic children $\left(2.73 \mathrm{ng} / \mathrm{m}^{3}\right)$ were not associated with a significantly elevated median $\mathrm{B}[a] \mathrm{P}$, compared to the atopic control children $(2.60 \mathrm{ng} /$ $\mathrm{m}^{3}$; JT P-value $\left.>0.05\right)$. Prevalence of OV/OB status was 3-times higher among the non-atopic asthmatic children (24\%) compared to that in the non-atopic controls $(8 \%$; $P$-value $<0.05)$. In contrast, the prevalence of $\mathrm{OV} / \mathrm{OB}$ asthma was about 2-times higher among the atopic asthmatic children (26\%), compared to that among the atopic controls $(14 \%$; P-value $>0.05)$. The lung function deficit was comparably high in both non-atopic asthmatic $(19 \%$; $P$-values $<0.05)$ and atopic asthmatic $(24 \%$; P-values $>0.05)$ children, compared to their respective controls ( $0 \%$ in both control groups).

As shown in Table 1, the non-atopic and atopic children demonstrate an overall disparate clinical diagnosis pattern at $\leq$ three years of age. The non-atopic asthmatic 
Table 1 Demographic and exposure traits in the sample, restricted to non-smoking children (i.e., urinary Cotinine $\leq 20$ ng/mg)

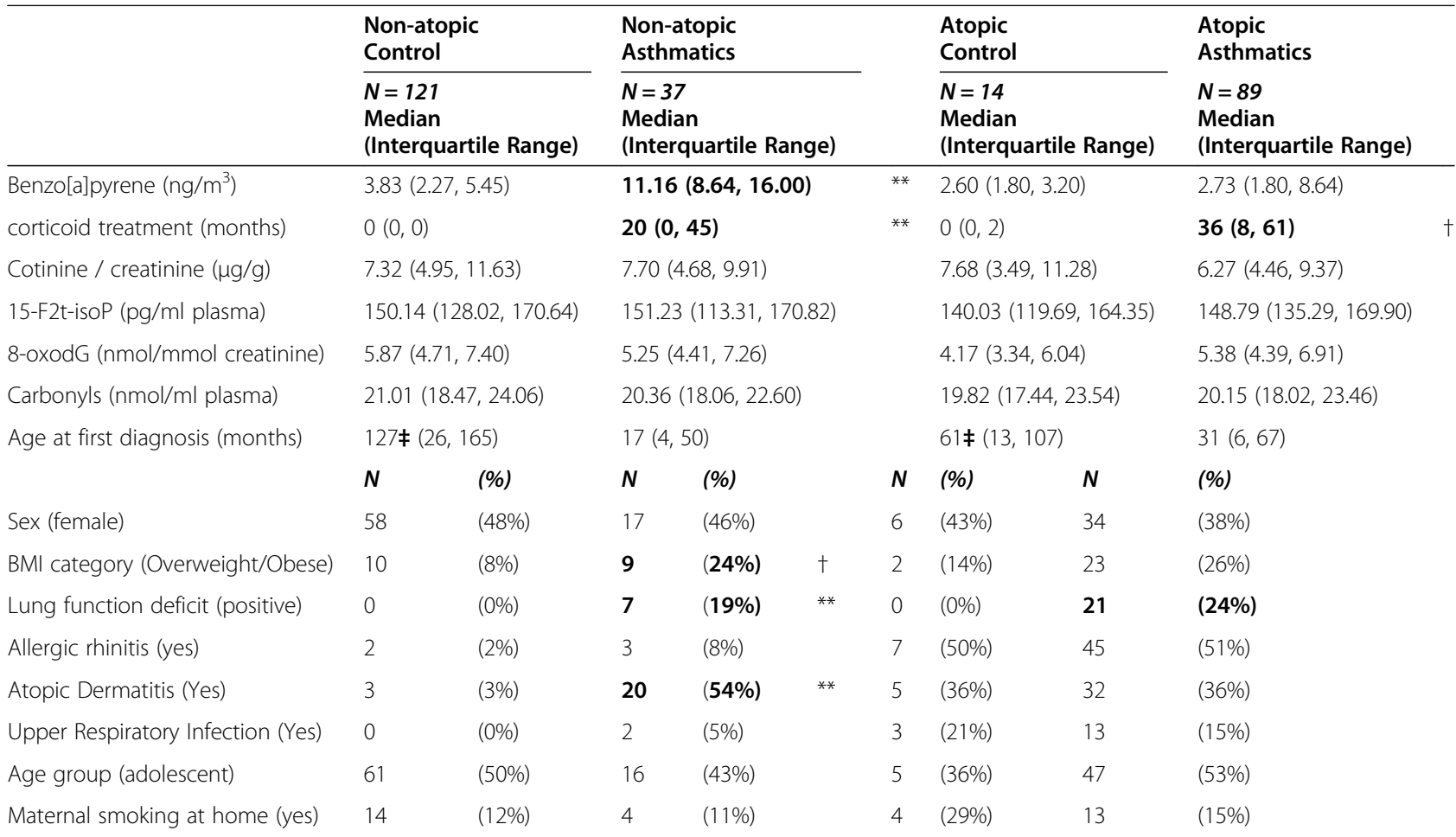

The symbols ** and + denote $P$-values $<0.001$ and 0.05 , respectively. $\neq$ Sample sizes for non-atopic control and atopic control children are 4 and 13 , respectively. Non-atopic and atopic asthma case sample sizes are 37 and 89, respectively. All categorical variables are tested using the Chi-square test of linear-by-linear association, and the continuous variables are tested using the Jonkheere-Terpestra test. All categorical variables are dichotomous and add up to $100 \%$. The reference category, which are not shown, are as follows: sex (male), BMI (lean), lung function deficit (negative), allergic rhinitis (no), atopic dermatitis (no), upper respiratory infection (no), age group (pre-adolescent), and maternal smoking (no)

children had their first clinical diagnosis around 17th months (IQR, 4-50 months; $P$-value > 0.05), compared to the non-atopic control, who were first diagnosed with any clinical outcome at 127th months (IQR, 26-165 months). Alternatively, the history of allergic rhinitis or upper respiratory infection at $\leq$ three years is most prevalent among the atopic control children (all $P$-values $>0.05$; Table 1). In contrast, non-atopic asthmatics (54\%) were associated with the highest prevalence of atopic dermatitis before age 3, compared to that in nonatopic controls $(3 \%$; P-value $<0.05)$.

\section{Sub-hypothesis 1: B[a]P-asthma association is significantly different for the non-atopic children and the atopic children}

As shown in Table 2 (A), the highest ambient $\mathrm{B}[\mathrm{a}] \mathrm{P}$ exposure category $\left(\geq 8.6 \mathrm{ng} / \mathrm{m}^{3}\right)$ was associated with the highest prevalence of the non-atopic lean asthma (65\%), compared to the prevalence in non-atopic controls $(6 \%$, $P$-value $<0.001$ ). Among the non-atopic girls (Table 2 (A)), the highest ambient $\mathrm{B}[a] \mathrm{P}$ exposure category $(\geq$ $8.6 \mathrm{ng} / \mathrm{m}^{3}$ ) was associated with the highest increase in the prevalence of asthma (94\%), compared to the nonatopic controls (10\%; P-values $<0.001)$. In contrast, neither the atopic asthmatic boys nor the atopic asthmatic girls were associated with the highest $\mathrm{B}[a] \mathrm{P}$ quartile exposure category, compared to their respective controls (both $P>0.05$; Table 2 (A)).

In particular, the highest $\mathrm{B}[a] \mathrm{P}$ quartile exposure category was associated with the highest prevalence of the lean asthma outcome (77\%) in non-atopic boys, compared to the non-atopic controls $(7 \%$, P-value $=0.020)$, and the OV/OB asthma outcome (100\%) in the nonatopic girls, compared to the non-atopic control girls (11\%, P-value $<0.001$, Table 2 (B)). The same exposure category $\left(\geq 8.6 \mathrm{ng} / \mathrm{m}^{3}\right)$ was also associated with the OV/ OB asthma outcome (64\%) in atopic girls, compared to the atopic control girls $(0 \%, P$-value $=0.013$, Table 2 (B)). In particular, non-atopic girls are associated with a step-wise increase in their median exposure to $\mathrm{B}[a] \mathrm{P}$ (see Fig. 1). For example, the non-atopic girls with lean asthma were associated with $11.16 \mathrm{ng} / \mathrm{m}^{3}$, whereas the non-atopic girls with $\mathrm{OV} / \mathrm{OB}$ asthmatic were associated with $18.00 \mathrm{ng} / \mathrm{m}^{3}$, compared to the non-atopic lean control girls (median, $4.28 \mathrm{ng} / \mathrm{m}^{3}$ ).

We account for the role of oxidative stress burden and lung function deficit in our final model (see Table 3 (A) and (B)). Based on the logistic regression model, on ln- 
Table 2 Children's exposure to B[a]P exposure quartile categories and prevalence of asthma outcome (coded as dichotomous outcome (A) and nominal outcome (B)), stratified by the atopy- and gender-status of the children. Categorical variables are tested using Chi-square test of linear-by-linear association

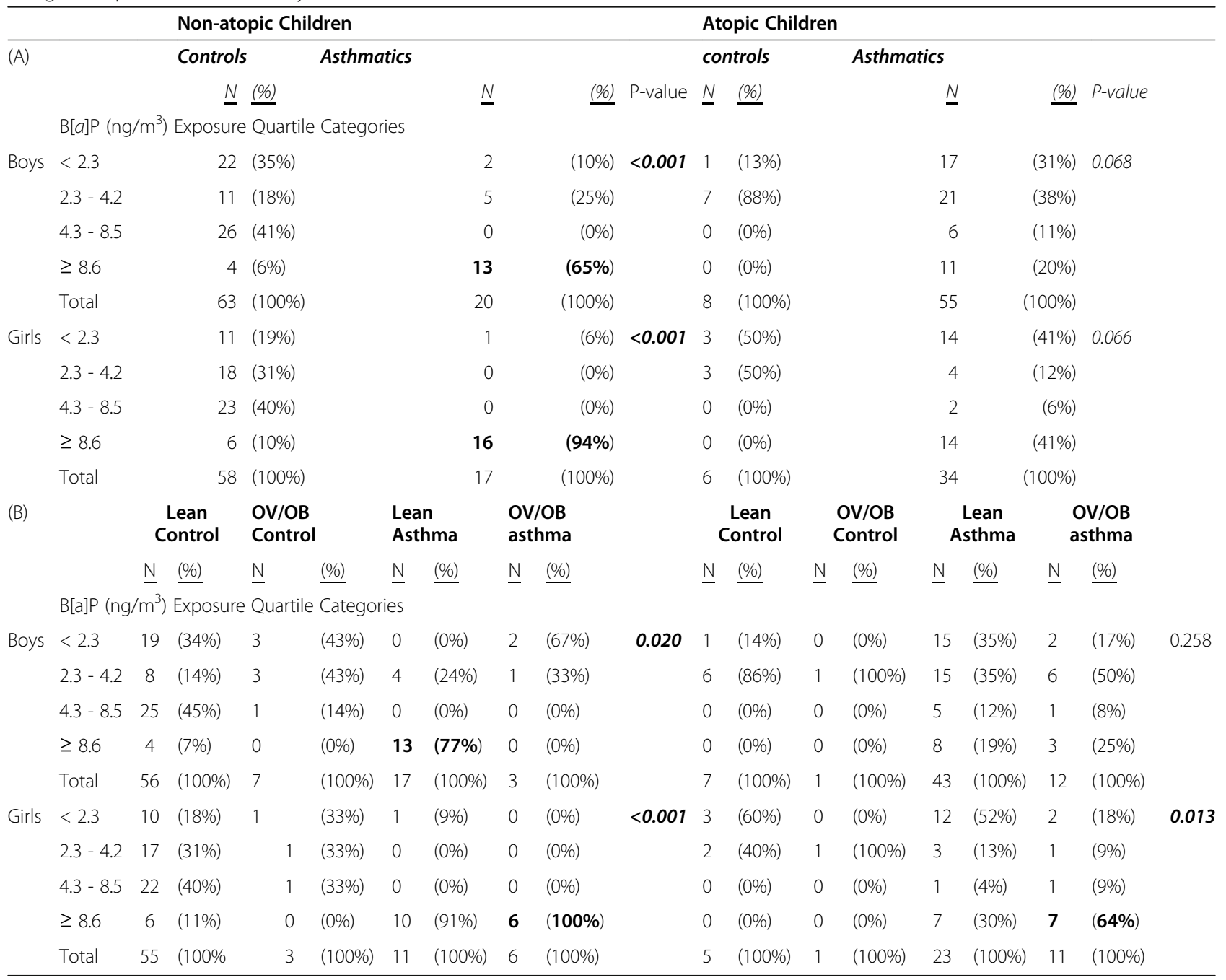

unit increate in $\mathrm{B}[a] \mathrm{P}$ is associated with 4.7-times greater odds $(95 \% \mathrm{CI}, 1.9-11.5, P=0.001)$ of asthma among the non-atopic boys. The same unit increase in $\mathrm{B}[a] \mathrm{P}$ is associated with 44.8 -times greater odds $(95 \%$ $\mathrm{CI}, 4.7-428.2, \mathrm{P}=0.001$ ) of asthma among the nonatopic girls. In contrast, neither the atopic boys nor the atopic girls are associated with a significant increase in the odds of asthma per unit increase in $\mathrm{B}[a] \mathrm{P}$.

\section{Sub-hypothesis 2: systemic oxidant burden and lung function deficit play divergent roles in non-atopic vs. atopic asthma per unit increase in $\mathrm{B}[\mathrm{a}] \mathrm{P}$ exposure}

As shown in Fig. 2, the non-atopic boys with a lung function deficit diagnosis and lean asthma are associated with the highest median $\mathrm{B}[a] \mathrm{P}\left(20.0 \mathrm{ng} / \mathrm{m}^{3}\right.$; IQR, $\left.16.0-24.5 \mathrm{ng} / \mathrm{m}^{3}\right)$. A second-highest median $\mathrm{B}[a] \mathrm{P}$ is observed in the non-atopic boys with lean asthma, but without the similar deficit $\left(10.3 \mathrm{ng} / \mathrm{m}^{3}\right.$; IQR, $2.7-$ $\left.16.0 \mathrm{ng} / \mathrm{m}^{3}\right)$, compared to that for the controls $\left(4.3 \mathrm{ng} / \mathrm{m}^{3}\right.$; IQR, $1.8-5.4 \mathrm{ng} / \mathrm{m}^{3}$, Fig. 2). Similarly, the non-atopic girls with lung function deficit are associated the highest median $\mathrm{B}[a] \mathrm{P}$ whether they had lean asthma $\left(20 \mathrm{ng} / \mathrm{m}^{3} ; \mathrm{IQR}\right.$, $\left.16.0-24.0 \mathrm{ng} / \mathrm{m}^{3}\right)$ or OV/OB asthma $\left(20 \mathrm{ng} / \mathrm{m}^{3}\right.$; IQR, $\left.16.0-20.0 \mathrm{ng} / \mathrm{m}^{3}\right)$, compared to that in the controls $(4.3$ $\mathrm{ng} / \mathrm{m}^{3}$; IQR, $2.6-6.0 \mathrm{ng} / \mathrm{m}^{3}$; Fig. 2). In contrast, the nonatopic girls without the lung function deficit demonstrate a more modest increase in the median $\mathrm{B}[a] \mathrm{P}$ among the lean asthmatics $\left(11.2 \mathrm{ng} / \mathrm{m}^{3}\right.$; IQR, $\left.8.6-11.2 \mathrm{ng} / \mathrm{m}^{3}\right)$ and OV/OB asthmatics $\left(10.3 \mathrm{ng} / \mathrm{m}^{3}\right.$; IQR, $\left.8.6-15.0 \mathrm{ng} / \mathrm{m}^{3}\right)$, compared to the non-atopic controls (Fig. 2).

Among the atopic boys, co-morbid presence of lung function deficit plus lean asthma $\left(2.7 \mathrm{ng} / \mathrm{m}^{3}\right.$; IQR, $1.9-$ $\left.9.3 \mathrm{ng} / \mathrm{m}^{3}\right)$, or the lung function deficit plus $\mathrm{OV} / \mathrm{OB}$ asthma $\left(1.8 \mathrm{ng} / \mathrm{m}^{3} ; \mathrm{IQR}, 1.5-9.3 \mathrm{ng} / \mathrm{m}^{3}\right)$ is not associated 


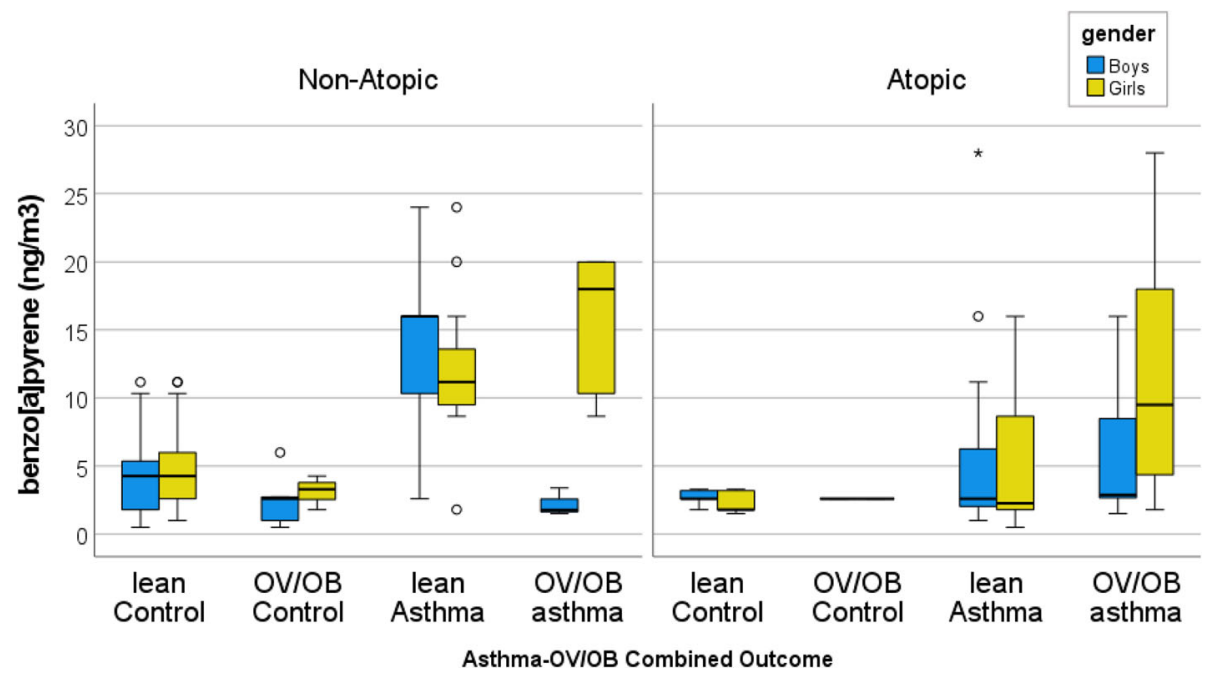

Fig. 1 The box (i.e., interquartile range and median) and whiskers (i.e., 5th and 95th percentile values) of ambient B[a]P concentrations for the boys (i.e., yellow bar) and the girls (i.e., green bar), according to the outcome categories (i.e., lean control, OV/OB control, lean asthma, and OV/OB asthma), and grouped according to gender and allergy status (non-atopic vs. atopic). The symbols $\mathrm{o}$ and ${ }^{*}$ represent values $>1.5-$ and $>3-$ fold, respectively, of the 75 th percentile value

with a different median $\mathrm{B}[a] \mathrm{P}$, compared to that in the atopic controls $\left(2.6 \mathrm{ng} / \mathrm{m}^{3}\right.$; IQR, 2.6-3.2 $\mathrm{ng} / \mathrm{m}^{3}$; Fig. 2). Among the atopic girls, only those with $\mathrm{OV} / \mathrm{OB}$ asthma as well as the lung function deficit are associated with a significantly elevated median $\mathrm{B}[a] \mathrm{P}\left(16.0 \mathrm{ng} / \mathrm{m}^{3}\right.$; IQR, 9.3-18.1 ng/ $\mathrm{m}^{3}$ ), followed by those with OV/OB asthma without the deficit $\left(9.1 \mathrm{ng} / \mathrm{m}^{3}\right.$; IQR, $\left.4.5-18.2 \mathrm{ng} / \mathrm{m}^{3}\right)$, compared to the median in the atopic control girls (1.8 $\mathrm{ng} / \mathrm{m}^{3}$; IQR, $1.7-3.3 \mathrm{ng} / \mathrm{m}^{3}$ ).

As shown in Fig. 3, the non-atopic versus the atopic asthmatic children are associated with an overall opposite trend in the relation between $\mathrm{B}[a] \mathrm{P}$ and systemic oxidant stress marker levels (i.e., $15-\mathrm{F}_{2 \mathrm{t}}$-IsoP and 8-oxodG levels, respectively). Among the non-atopic asthmatic boys and girls, those with the highest median $\mathrm{B}[a] \mathrm{P}$ are associated with lower than the median $15-\mathrm{F}_{2 \mathrm{t}}$-IsoP $(<150.07 \mathrm{pg} / \mathrm{ml})$, compared to that in the respective non-atopic controls. For example, the non-atopic boys, a highest median $\mathrm{B}[\mathrm{a}] \mathrm{P}$ $\left(16.0 \mathrm{ng} / \mathrm{m}^{3}\right.$; IQR, $\left.10.3-24.0 \mathrm{ng} / \mathrm{m}^{3}\right)$ and the lean asthma outcome are observed among those with a lower than the median $15-\mathrm{F}_{2 \mathrm{t}}-\mathrm{IsoP}$, compared to $\mathrm{B}[a] \mathrm{P}$ in the non-atopic control boys (median, $3.8 \mathrm{ng} / \mathrm{m}^{3}$; IQR, $1.7-6.0 \mathrm{ng} / \mathrm{m}^{3}$ ). Similarly, not only the non-atopic girls with the highest $\mathrm{B}[\mathrm{a}] P$ value (median, $20.0 \mathrm{ng} / \mathrm{m}^{3}$; IQR, $13.0-20.0 \mathrm{ng} / \mathrm{m}^{3}$ ) and $\mathrm{OV} / \mathrm{OB}$ asthma outcome but also those with a second-highest median $\mathrm{B}[a] \mathrm{P}\left(11.2 \mathrm{ng} / \mathrm{m}^{3}\right.$; IQR, 8.2-17.0 $\mathrm{ng} / \mathrm{m}^{3}$ ) and lean asthma are both associated with lower than the median $15-\mathrm{F}_{2 \mathrm{t}}$-IsoP $(<150.07 \mathrm{pg} / \mathrm{ml})$, compared to the median $\mathrm{B}[a] \mathrm{P}$ in the non-atopic control girls (median, $4.4 \mathrm{ng} / \mathrm{m}^{3}$; IQR, $2.6-6.0 \mathrm{ng} / \mathrm{m}^{3}$ ).

In contrast, an opposite trend is observed among the atopic children. Namely, the atopic girls with lean asthma have not only a high median $\mathrm{B}[\mathrm{a}] \mathrm{P}(5.8 \mathrm{ng} / \mathrm{m} 3$; IQR, 1.8-11.2 $\mathrm{ng} / \mathrm{m} 3$ ) but also a higher than the median $15-\mathrm{F}_{2 \mathrm{t}}$-IsoP (Fig. 3). Furthermore, the atopic girls with $\mathrm{OV} / \mathrm{OB}$ asthma not only have an even higher exposure to $\mathrm{B}[a] \mathrm{P}$ (median, $16.0 \mathrm{ng} / \mathrm{m}^{3} \mathrm{IQR}, 5.6-28.0 \mathrm{ng} / \mathrm{m}^{3}$ ) but also possess a higher than the median $15-\mathrm{F}_{2 \mathrm{t}}$-IsoP value $(\geq 150.07 \mathrm{pg} / \mathrm{ml}$ ), compared to the $\mathrm{B}[a] \mathrm{P}$ in the atopic control girls (median, $1.5 \mathrm{ng} / \mathrm{m}^{3} \mathrm{IQR}, 1.5-1.5 \mathrm{ng} / \mathrm{m}^{3}$ ). Furthermore, the scatterplots (Fig. 4) of $15-\mathrm{F}_{2 \mathrm{t}}$-IsoP against $\mathrm{B}[\mathrm{a}] \mathrm{P}$ shows overall divergent associations between non-atopic and atopic OV/OB girls. Whereas the non-atopic OV/OB girls demonstrate an inverse association between $15-\mathrm{F}_{2 \mathrm{t}}$-IsoP and $\mathrm{B}[\mathrm{a}] \mathrm{P}$ (Spearman's rho = $-0.797 ; p$-value $=0.010)$, the association is weakly null among the atopic OV/OB girls (Fig. 4).

When we alternatively stratify the same children, according to their overall median 8-oxodG $(5.68 \mathrm{nmol} /$ mmol Creatinine; Fig. 5), an overall similar trend as those in $15-\mathrm{F}_{2 \mathrm{t}}$-IsoP is observed. Specifically, the nonatopic girls with a highest median $\mathrm{B}[a] \mathrm{P}\left(20.0 \mathrm{ng} / \mathrm{m}^{3}\right.$ IQR, 10.3-. $\mathrm{ng} / \mathrm{m}^{3}$ ) and $\mathrm{OV} / \mathrm{OB}$ asthma, or the secondhighest median $\mathrm{B}[\mathrm{a}] \mathrm{P}\left(11.2 \mathrm{ng} / \mathrm{m}^{3} \mathrm{IQR}, 8.6-18.0 \mathrm{ng} / \mathrm{m}^{3}\right)$ and the lean asthma are observed among those children with lower than the median 8-oxodG, compared to the non-atopic controls (median, $3.3 \mathrm{ng} / \mathrm{m}^{3} \mathrm{IQR}, 2.6-5.3 \mathrm{ng} /$ $\left.\mathrm{m}^{3}\right)$. In contrast, the atopic girls with a highest median $\mathrm{B}[a] \mathrm{P}\left(18.3 \mathrm{ng} / \mathrm{m}^{3} \mathrm{IQR}, 6.7-28.0 \mathrm{ng} / \mathrm{m}^{3}\right)$-, as well as an $\mathrm{OV} / \mathrm{OB}$ asthma, or the atopic girls with a second-highest median B[a]P (5.8 ng/m3 IQR, 1.6-12.4 ng/m3) and lean asthma, are observed among those with a higher than the median 8-oxodG, compared to the atopic control girls (median, $1.8 \mathrm{ng} / \mathrm{m}^{3} \mathrm{IQR}, 1.8-1.8 \mathrm{ng} / \mathrm{m}^{3}$; Fig. 5). 
Table 3. Adjusted odds of asthma (coded as either dichotomous outcome (A) or multinomial outcome (B)) per unit increase in exposure to natural-log transformed $\mathrm{B}[a] \mathrm{P}$ and stratified according to atopy- and sex-

\begin{tabular}{|c|c|c|c|c|c|c|c|c|c|}
\hline \multirow{2}{*}{\multicolumn{2}{|c|}{$\begin{array}{ll}\text { Main } \\
\text { exposure }\end{array}$}} & \multicolumn{8}{|c|}{ Main Health Outcome groups of interest } \\
\hline & & Non-atopic Ch & & & & Atopic Childre & & & \\
\hline \multirow[t]{4}{*}{ (A). } & & $\begin{array}{l}\text { Control } \\
\text { (Reference) }\end{array}$ & & & Asthmatics & $\begin{array}{l}\text { Control } \\
\text { (Reference) }\end{array}$ & & & Asthmatics \\
\hline & & $N$ & & & N & N & & & N \\
\hline & & OR $(95 \% \mathrm{Cl})$ & & & OR $(95 \% \mathrm{Cl})$ & OR $(95 \% \mathrm{Cl})$ & & & OR $(95 \% \mathrm{Cl})$ \\
\hline & & P-value & & & P-value & P-value & & & P-value \\
\hline \multirow[t]{3}{*}{ Male } & one In-unit & $N=63$ & & & $N=20$ & $N=8$ & & & $N=55$ \\
\hline & & 1 & & & $\begin{array}{l}4.7 \\
(1.9-11.5)\end{array}$ & 1 & & & $\begin{array}{l}2.0 \\
(0.4-11.1)\end{array}$ \\
\hline & & & & & $P=0.001$ & & & & $P=0.331$ \\
\hline \multirow[t]{3}{*}{ Female } & one In-unit & $N=58$ & & & $N=1$ & $N=6$ & & & $N=34$ \\
\hline & & 1 & & & $\begin{array}{l}44.8 \\
(4.7-428.2)\end{array}$ & 1 & & & $\begin{array}{l}3.0 \\
(0.7-12.7)\end{array}$ \\
\hline & & & & & $P=0.001$ & & & & $P=0.173$ \\
\hline \multirow[t]{4}{*}{ (B). } & & $\begin{array}{l}\text { Lean Control } \\
\text { (Reference) }\end{array}$ & $\begin{array}{l}\text { OV/OB } \\
\text { Control }\end{array}$ & $\begin{array}{l}\text { Lean } \\
\text { Asthmatics }\end{array}$ & $\begin{array}{l}\text { OV/OB } \\
\text { Asthmatics }\end{array}$ & $\begin{array}{l}\text { Lean Control } \\
\text { (reference) }\end{array}$ & $\begin{array}{l}\text { OV/OB } \\
\text { Control }\end{array}$ & $\begin{array}{l}\text { Lean } \\
\text { Asthmatics }\end{array}$ & $\begin{array}{l}\text { OV/OB } \\
\text { Asthmatics }\end{array}$ \\
\hline & & N & N & $N$ & N & $N$ & $N$ & $N$ & N \\
\hline & & OR $(95 \% \mathrm{Cl})$ & $\begin{array}{l}\text { OR }(95 \% \\
\mathrm{Cl}) \mathrm{c}\end{array}$ & OR $(95 \% \mathrm{Cl})$ & OR $(95 \% \mathrm{Cl})$ & OR $(95 \% \mathrm{Cl})$ & $\begin{array}{l}\text { OR }(95 \% \\
\mathrm{Cl})\end{array}$ & OR (95\% Cl) & OR (95\% Cl) \\
\hline & & P-value & P-value & $P$-value & $P$-value & P-value & P-value & P-value & P-value \\
\hline \multirow[t]{3}{*}{ Male } & one In-unit & $N=56$ & $N=7$ & $N=17$ & $N=3$ & $N=7$ & $N=1$ & $N=43$ & $N=12$ \\
\hline & & 1 & $\begin{array}{l}0.3 \\
(0.1-1.0)\end{array}$ & $\begin{array}{l}9.6 \\
(2.9-32.1)\end{array}$ & $0.3(0.1-2.1)$ & 1 & $\begin{array}{l}0.4 \\
(0.0-173.1)\end{array}$ & $\begin{array}{l}1.6 \\
(0.3-9.7)\end{array}$ & $\begin{array}{l}2.2 \\
(0.3-14.9)\end{array}$ \\
\hline & & & $P=0.054$ & $P<0.001$ & $P=0.247$ & & $P=0.786$ & $P=0.594$ & $P=0.409$ \\
\hline \multirow[t]{3}{*}{ Female } & one In-unit & $N=55$ & $N=3$ & $N=11$ & $N=6$ & $N=5$ & $N=1$ & $N=23$ & $N=11$ \\
\hline & & 1 & $\begin{array}{l}0.3 \\
(0.0-2.9)\end{array}$ & $\begin{array}{l}27.4 \\
(3.2-237.1)\end{array}$ & $\begin{array}{l}46.1 \\
(1.7-1271.4)\end{array}$ & 1 & $\begin{array}{l}0.0 \\
(0.0-0.0)\end{array}$ & $\begin{array}{l}3.6 \\
(0.6-23.3)\end{array}$ & $\begin{array}{l}17.1 \\
(1.8-165.6)\end{array}$ \\
\hline & & & $P=0.286$ & $P=0.003$ & $P=0.024$ & & $P=0.998$ & $P=0.173$ & $P=0.014$ \\
\hline
\end{tabular}

The dichotomous outcome model adjusts for Creatinine adjusted Cotinine, (In) 15-F-2t-IsoP, (In) 8-oxodG, and lung function deficit. The models adjust for Cotinine, lung function deficit, 15-F2t-IsoP, and 8-oxodG

Table 3 (B) summarizes the odds of multinomial asthma outcomes per unit increase in ambient $\mathrm{B}[\mathrm{a}] \mathrm{P}$ concentration in non-atopic and atopic boys and girls. An (ln)-unit increase $\mathrm{B}[\mathrm{a}] \mathrm{P}$ predicts approximately 10 times greater odds of asthma for the non-atopic boys with lean asthma (Table 3 (B)). Such estimate remains consistently robust, after controlling for Cotinine alone (aOR: 10.3; 95\% CI: 3.2-33.1; $P<0.001$; Table S1, Model A), Cotinine and lung function deficit (aOR: 9.0; 95\% CI: 2.8 to 29.3; $P<0.001$; Table S1, Model B), Cotinine, lung function deficit, and 15-F2t-IsoP (aOR: 9.4; 95\% CI: 2.9 to 31.0; $P<0.001$; Table S1, Model C), and finally, Cotinine, lung function deficit, 15-F2t-IsoP, and 8-oxodG (aOR: 9.6; 95\% CI: 2.9 to $32.1 ; P<0.001$; Table S1, Model D), per unit exposure to $\mathrm{B}[a] \mathrm{P}$. In contrast, the same unit exposure to $\mathrm{B}[a] \mathrm{P}$ among the non-atopic girls is associated with a dramatic reduction in asthma effect sizes following a stepwise adjustment for the same set of confounders (Table S1, Model A-D). For example, among the non-atopic girls with $\mathrm{OV} / \mathrm{OB}$ asthma, the aOR changes from 301.2 (95\% CI: 11.0-8231.9; $P=$ 0.001 ) adjusting for cotinine (Table S1, Model A); to 139.7 (95\% CI: $3.2-6120.7 ; P=0.010$ ) adjusting for cotinine and the lung function deficit (Table S1, Model B); to 71.2 (95\% CI: 2.0-2563.5; $P=0.020$ ) adjusting for cotinine, the lung function deficit, and $15-\mathrm{F}_{2 \mathrm{t}}$-IsoP (Table S1, Model C); and to 46.1 (95\% CI: $2.0-1271.4 ; P=0.024$ ) adjusting for cotinine, the lung function deficit, $15-\mathrm{F}_{2 \mathrm{t}^{-}}$ IsoP, and 8-oxodG (Table 3 (B)).

On the other hand, the lean atopic children are not associated with elevated odds of asthma per unit change in $\mathrm{B}[a] \mathrm{P}$ (Table 3). However, the only exception to such trend is observed among the atopic girls with $\mathrm{OV} / \mathrm{OB}$ asthma, in whom a unit increase in $\mathrm{B}[a] \mathrm{P}$ is associated 


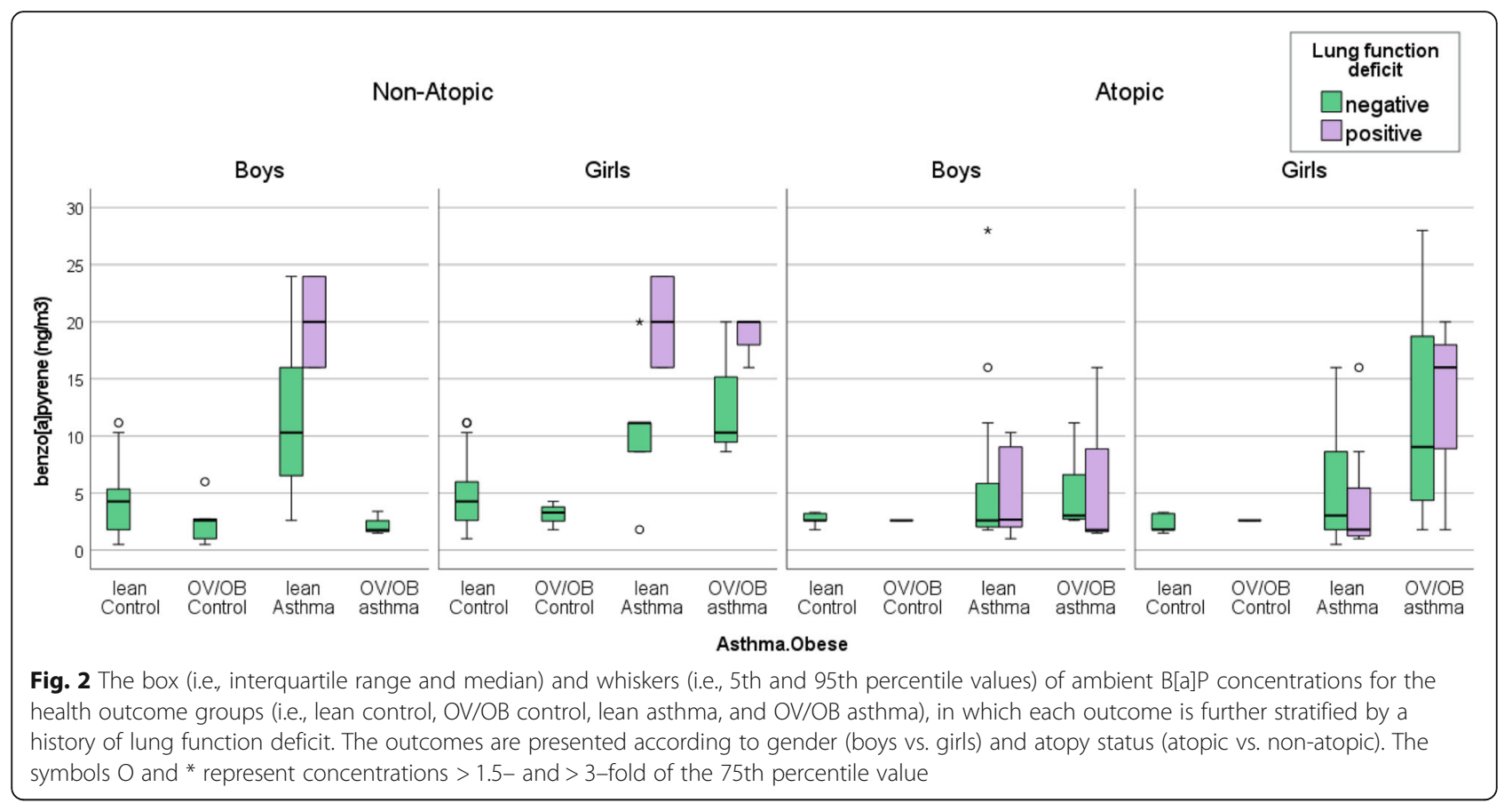

with 5.9-times higher odds, following an adjustment for lung function deficit and Cotinine (95\% CI: 1.1-31.3; $P=0.038) ;$ 7.6-times higher odds, following Cotinine, the lung function deficit, as well as $15-\mathrm{F}_{2 \mathrm{t}}$-IsoP $(95 \% \mathrm{CI}$ : $1.2-49.1 ; P=0.034)$; and 17.1-times higher odds, following an adjustment for Cotinine, the lung function deficit, 15- $\mathrm{F}_{2 \mathrm{t}}$-IsoP, and 8-oxodG (95\% CI: 1.8-165.6; $P=0.014$; Table 3 (B)).
Sub-hypothesis 3: B[a]P association with the non-atopic $O V / O B$ asthmatic girls are different from the B[a]P association with atopic $\mathrm{OV} / \mathrm{OB}$ asthmatic girls

$\mathrm{A}$ unit increase in ambient $\mathrm{B}[a] \mathrm{P}$ concentration is associated with 46.1-times greater odds of $\mathrm{OV} / \mathrm{OB}$ asthma (95\% CI: $1.7-1271.4 ; P=0.024$ ) among the non-atopic girls, adjusting for Cotinine, the lung function deficit, 15- $\mathrm{F}_{2 \mathrm{t}}$-IsoP, and 8-oxodG (Table 3 (B)). In contrast, the

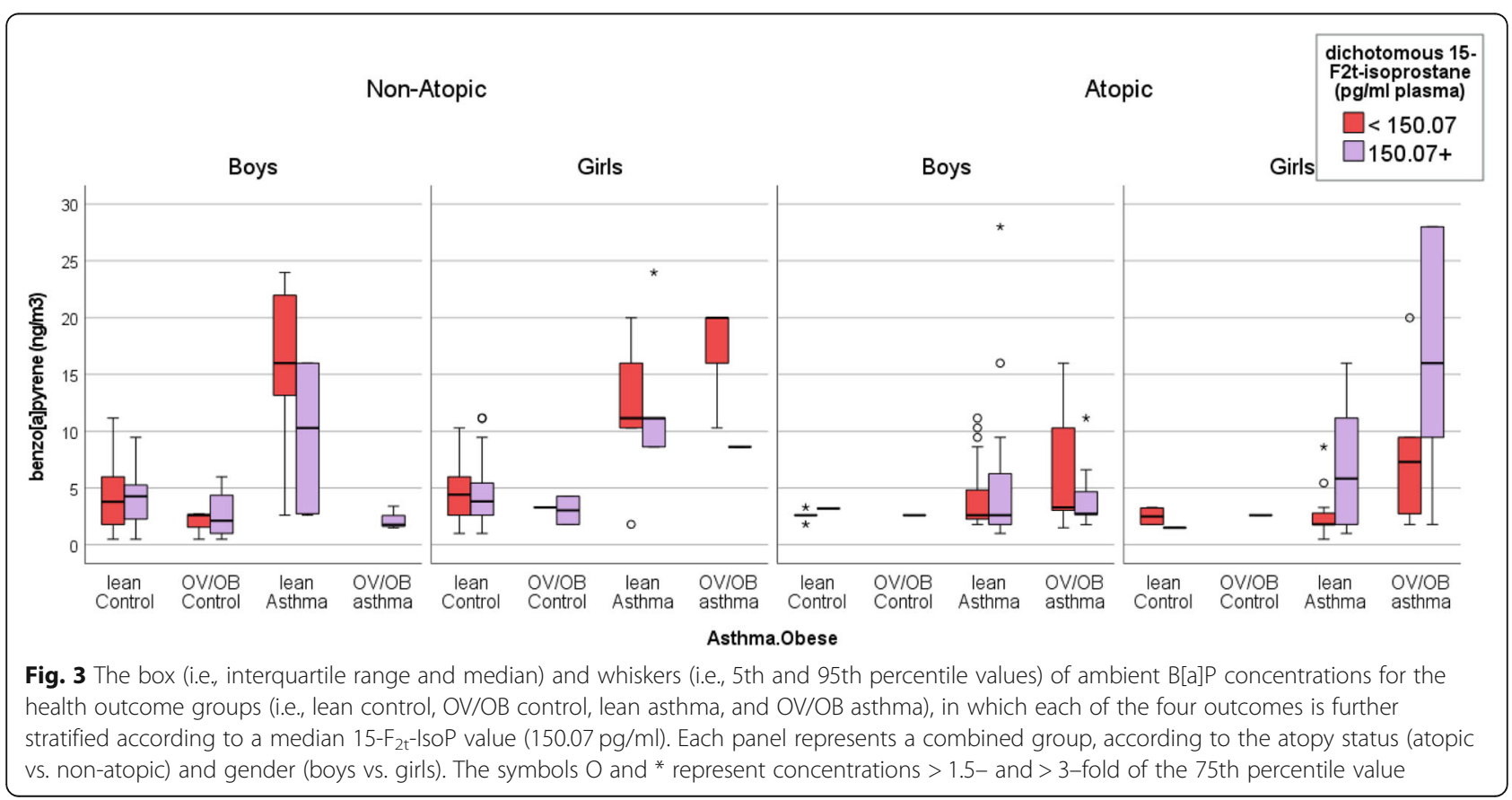



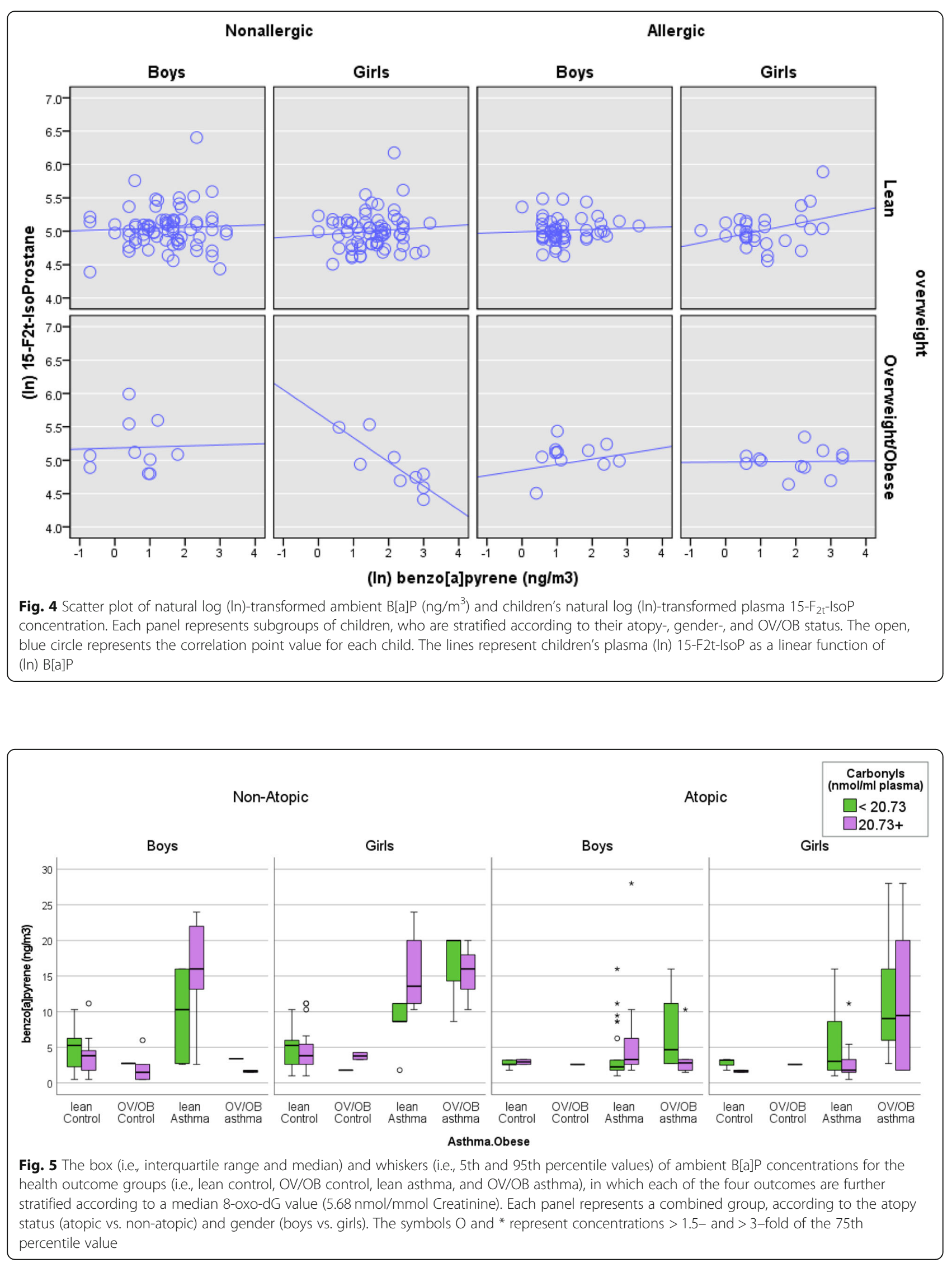
same unit increase in $\mathrm{B}[a] \mathrm{P}$ among the atopic girls is associated with 17.1-times higher odds of OV/OB asthma following an adjustment for the same set of covariates (95\% CI: 1.8-165.6; $P=0.014$; Table 3 (B)).

\section{Discussion}

Here, we characterize exposure to ambient $\mathrm{B}[a] \mathrm{P}$ concentration and its role in non-atopic or atopic asthma as a proxy for non-Th2 and Th2-high endotypes, respectively. To the best of our knowledge, our analysis demonstrates for the first time that the childhood exposure level to $\mathrm{B}[\mathrm{a}] \mathrm{P}$ and the roles of two systemic oxidant markers, $15-\mathrm{F}_{\mathrm{t} 2}$-isoP and 8-oxodG, are markedly divergent between the non-atopic asthmatic versus atopic asthmatic children. Our postulate of endotypes is further supported by the overall dissimilar pattern of co-morbid events during the children's first three years of life, preceding the current asthma diagnosis. Namely, the socalled atopic march (e.g., allergic rhinitis, upper respiratory infection) is absent among non-atopic asthmatic children. On the other hand, the atopic control children demonstrate the highest prevalence of the atopic march diagnoses.

Furthermore, contrary to the current body of evidence supporting adulthood onset of non-atopic asthma [37], our data suggest for the first time that the lung function deficit during early childhood a critical sentinel event preceding non-atopic asthma. Collectively, the following lines of evidence suggest that childhood exposures to $\mathrm{B}[a] \mathrm{P}$ contribute toward non-atopic asthma. At the same time, the atopic one arises through $\mathrm{B}[a] \mathrm{P}$-independent mechanisms among the lean children.

First, among the lean children, $\mathrm{B}[a] \mathrm{P}$ is not associated with elevated odds of atopic asthma, while it is associated with a robust increase in the odds of non-atopic asthma. For example, a unit $\mathrm{B}[a] \mathrm{P}$ exposure is not associated with asthma among the lean atopic boys, while the same exposure predicts 10-times greater odds of asthma in the lean non-atopic boys. The non-atopic asthmatic boys with the highest exposure to $\mathrm{B}[a] \mathrm{P}$ (median, $20 \mathrm{ng} / \mathrm{m}^{3}$ ) were also positively diagnosis with lung function deficit, compared to the non-atopic controls (median, $4.3 \mathrm{ng} / \mathrm{m}^{3}$ ). In contrast, in the lean atopic boys, median $\mathrm{B}[a] \mathrm{P}$ was uniformly low in those with or without the deficit and with or without asthma. Such trends suggest that childhood exposure to elevated $\mathrm{B}[a] \mathrm{P}$ level contributes toward the development of non-atopic asthma, while atopic asthma occurs through $\mathrm{B}[a] \mathrm{P}$-independent mechanisms in lean children.

Second, $\mathrm{B}[a] \mathrm{P}$ is associated with plasma $15-\mathrm{F}_{2 \mathrm{t}}$-IsoP and urinary 8-oxodG, respectively, in an opposite fashion between the children with non-atopic versus atopic asthma. While $\mathrm{B}[a] \mathrm{P}$ and $\mathrm{F}_{2 \mathrm{t}}$-isoP are inversely associated among the non-atopic OV/OB girls, the same association is null among the atopic OV/OB girls (Fig. 4). Among the non-atopic lean girls, the same association is also weakly positive. Such non-linear doseresponse suggests the ambient $\mathrm{B}[a] \mathrm{P}$ concentration might pose a pro-inflammatory risk at low concentration, which subsequently switches to anti-inflammatory mechanism activation beyond a certain threshold $\mathrm{B}[a] \mathrm{P}$ level [38]. Earlier investigations support hierarchical oxidative stress phases posed by multiple oxidants within air pollution exposures [39]. At low exposure concentration, the ambient $\mathrm{B}[a] \mathrm{P}$ poses a pro-inflammatory risk, which subsequently switches to anti-inflammatory mechanism activation beyond a certain threshold [38]. Moreover, the adjustment for $\mathrm{F}_{2 \mathrm{t}}$-isoP and 8-oxodG, respectively, in the regression models is associated with significant decrements in $\mathrm{B}[\mathrm{a}] \mathrm{P}$-asthma effect sizes nonatopic girls (Table 3 ). In contrast, the same covariate adjustments are associated with increased $\mathrm{B}[a] \mathrm{P}$-asthma associations among the atopic girls. Such divergent trends suggest that $\mathrm{B}[a] \mathrm{P}$ might initiate and exacerbate distinct non-atopic versus atopic asthma mechanisms. Our earlier analyses have shown robust activation of anti-inflammatory mechanisms in children with high $\mathrm{B}[a] \mathrm{P}$ exposure as well as a severe outcome [19]. Thus, while $\mathrm{F}_{2 \mathrm{t}}$-isoP and 8-oxodG concentrations seem suppressed among those who develop non-atopic asthma, the same oxidants appear to pose a mildly proinflammatory role in the atopic girls and corresponding increased odds of atopic OV/OB asthma (Table 3, Figs. 3 and 4).

Third, the question of whether OV/OB asthma represents a unique endotype or phenotypic consequence that remains unanswered $[4,10]$. While multiple endotype might exist within so-called $\mathrm{OV} / \mathrm{OB}$ asthma during adulthood, a unit $\mathrm{B}[a] \mathrm{P}$ exposure is associated with vastly different estimates between non-atopic and the atopic girls within our case-control children (Table $3(\mathrm{~B}))$. Among the non-atopic girls, a unit $\mathrm{B}[\mathrm{a}] \mathrm{P}$ exposure is associated with a step-wise increase in the odds of lean asthma (aOR, 27.4; 95\% CI: 3.2 to 237.1) and OV/ OB asthma (aOR, 46.1; 95\% CI: 1.7 to 1271.4 ), respectively. In contrast, the same unit exposure is associated with markedly lower odds of OV/OB asthma (aOR, 17.1; 95\% CI: 1.8 to 165.6) among the atopic girls. Overall, the $\mathrm{B}[a] \mathrm{P}$ effect sizes differ more dramatically between the non-atopic and atopic children than between the lean and OV/OB children within either the non-atopic or atopic group. Our data suggest OV/OB asthma as a severe outcome, nested within the non-atopic asthma endotype, rather than constituting a unique endotype.

Fourth, the lung function deficit, which only appears among those with the highest median value of $\mathrm{B}[a] \mathrm{P}$, appears to be a particularly significant predictor of non-atopic asthma only. Overall, non- 
atopic boys with the highest median $\mathrm{B}[\mathrm{a}] \mathrm{P}$ exposure are associated with lung function deficit, as well as elevated odds of lean asthma. In contrast, the lean atopic boys and girls with low median $\mathrm{B}[a] \mathrm{P}$ exposure are neither associated with the lung function deficit diagnosis nor asthma. Such a trend suggests that processes underlying non-atopic asthma might be distinct from those for atopic asthma among the boys. Lung function impairment appears to be a 'meet-in-the-middle' biomarker of $\mathrm{B}[a] \mathrm{P}$ and asthma association. Above a certain threshold for exposure, $\mathrm{B}[a] \mathrm{P}$ are associated with asthma, regardless of the atopy status. Even though spirometry-based lung function measurement is commonly considered a diagnostic criterion, Table 1 demonstrates that $81 \%$ of non-atopic asthmatic children and $76 \%$ of atopic asthmatic children are asthmatic without having lung function impairments. Several international diagnostic consensus statements noted that a considerable proportion of asthmatic children have normal lung function [40]. Instead, lung function impairment is significantly associated with severe, corticosteroid therapy-resistant asthma [3, 10, 41].

The strengths and limitations of the present study have been discussed $[18-20,23]$. Briefly, $\mathrm{B}[a] \mathrm{P}$ is used as a representative $\mathrm{PAH}$ compound here, while a more realistic exposure scenario involves exposure to a complex mixture of air pollutants. At the same time, a robust body of evidence, including our own, has demonstrated $\mathrm{B}[a] \mathrm{P}$ as an etiologically pertinent and representative PAH compound $[17,18,20,23$, 42-46]. Both the laboratory and epidemiologic evidence have shown that PAHs could induce or enhance allergic sensitization, exacerbate pre-existing asthma, and enhance the risk of de novo asthma development $[44,47,48]$. In particular, $\mathrm{B}[\mathrm{a}] \mathrm{P}$ has been shown to directly target hematopoietic stem cells by binding to aryl hydrocarbon receptors and subsequently impart a wide array of adverse effects, including mitochondrial functional deficit [49].

Furthermore, $\mathrm{B}[a] \mathrm{P}$ represents an efficient indicator of a child's exposure to ambient pollutant mixture due to its extremely high correlation with other traffic-related air pollutants [50-53]. At the same time, other constituents of complex mixtures could increase multiple types of oxidative injury, respiratory system inflammation, and alteration in lung structure and function [42]. Thus, other unmeasured yet correlated air pollutants (e.g., metals) may pose a threat of residual confounding.

Our earlier investigation has shown the ambient monitored PAH concentrations as an apt marker of chronic exposure. For example, the interquartile range of ambient $\mathrm{B}[a] \mathrm{P}$ levels during our exposure window of interest (i.e., November 2008) is representative of the ambient concentrations from the earlier years [23]. However, using ambient monitoring as the primary marker of chronic exposure might underestimate exposure from other routes (e.g., oral and dermal). Our earlier sensitivity analysis has shown that while both the dietary intake and the inhalation exposure to PAHs contribute to the human body burden, inhalation represents the predominant route of exposure during the heating season [54].

Another limitation of our investigation includes our lack of measurement for a full suite of cells and cytokines associated with Th 2 vs. non-Th2 endotypes. Thus, a more comprehensive characterization of the two asthmas in terms of the repertoire of cytokines, cells, and clinical traits of the children is warranted in future investigations. Also, as our goal was to estimate a proofof-principle dose-response function of asthma associations under extreme variations in ambient $\mathrm{B}[a] \mathrm{P}$ concentrations, our case-control children are not representative of the general Czech population.

\section{Conclusion}

Within our case-control study, the non-atopic and atopic asthma are associated with distinct pathophysiologic processes, in which the non-atopic asthma is $\mathrm{B}[a] \mathrm{P}$-dependent, while the atopic one is $\mathrm{B}[a] \mathrm{P}$-independent. Elevated exposure to $\mathrm{B}[a] \mathrm{P}$ is associated with depressed systemic oxidant levels and correspondingly elevated odds of non-atopic asthma. On the other hand, low ambient exposure to $\mathrm{B}[a] \mathrm{P}$, and the weakly proinflammatory effect of oxidative stress of such exposure, is not associated with atopic asthma

\section{Abbreviations}

PAH: Polyaromatic hydrocarbon; OV/OB: Overweight/obese; B[a]P: Benzo[a]pyrene; 15- $\mathrm{F}_{2 \mathrm{t}}$-IsoP: 15- $\mathrm{F}_{\mathrm{t} 2}$-isoprostane; 8-oxodG: 8-oxo-7,8dihydro-2'-deoxyguanosine; JT: Jonkheere-Terpestra; IQR: Interquartile range

\section{Supplementary Information}

The online version contains supplementary material available at https://doi. org/10.1186/s12940-021-00711-4

\section{Additional file 1.}

\section{Acknowledgments}

We thank Dr. Eva Schallerova, Ostrava-Radvanice, and other pediatricians from the district of Prachatice for facilitating the collection of blood and urine samples from the children.

\section{Authors' contributions}

Hyunok Choi conducted conceptualization, formal analysis, investigation, methodology, software, investigation, writing - original draft, and visualization. Miroslav Dostal performed data curation, resources. Anna Pastorkova performed data curation, resources. Pavel Rossner, Jr. performed conceptualization, data curation, resources, and writing- reviewing and editing. Radim Sram performed project administration, funding acquisition, writing- reviewing and editing. 


\section{Funding}

This work is supported by the Czech Ministry of the Environment [grant number SP1b35007]; Czech Ministry of Education [grant number 2B08005]; and Academy of Sciences, Czech Republic [grant number AVOZ50390703]; ERDF/ESF project "Healthy Aging in Industrial Environment HAIE" (No. CZ.02.1.01/0.0/0.0/16_019/0000798). All authors declare that they have no financial conflicts to disclose. The funding sources are not involved in the research or the preparation of the present article. The institutional review board at the Institute of Experimental Medicine, Academy of Science, Czech Republic, reviewed and approved the study.

\section{Availability of data and materials}

The data that support the findings of this study are available from the Institute of Experimental Medicine, Academy of Sciences of the Czech Republic, but restrictions apply to the availability of these data, which were used under license for the current study, and so are not publicly available. Data are, however, available from the authors upon reasonable request and with permission of the Institute of Experimental Medicine, Academy of Sciences of the Czech Republic.

\section{Declarations}

\section{Ethics approval and consent to participate}

The ethics committee of the Institute of Experimental Medicine, Academy of Sciences of the Czech Republic, approved the study. The parents of the children signed informed consent, according to the Helsinki II declaration.

\section{Consent for publication}

Not applicable.

\section{Competing interests}

The authors declare that they have no competing interests.

\section{Author details}

${ }^{1}$ College of Health, Lehigh University, Bethlehem, PA, USA. ${ }^{2}$ Department of Genetic Toxicology and Nanotoxicology, Institute of Experimental Medicine, Czech Academy of Sciences, Prague, Czech Republic.

\section{Received: 8 July 2020 Accepted: 1 March 2021}

\section{Published online: 09 April 2021}

\section{References}

1. Ferrante G, La Grutta S, et al. Front. Pediatr. 2018:186. https://doi.org/10.33 89/fped.2018.00186.

2. Hay SI, Jayaraman SP, Truelsen T, Sorensen RJD, Millear A, Giussani G, et al. GBD 2015 disease and injury incidence and prevalence collaborators. Global, regional, and national incidence, prevalence, and years lived with disability for 310 diseases and injuries, 1990-2015: a systematic analysis for the global burden of disease stud. Lancet. 2017;389:E1-E1. ELSEVIER SCIENCE INC 360 PARK AVE SOUTH, NEW YORK, NY 10010-1710 USA.

3. Moore WC, Meyers DA, Wenzel SE, Teague WG, Li H, Li X, et al. Identification of asthma phenotypes using cluster analysis in the Severe Asthma Research Program. Am J Respir Crit Care Med. 2010;181:315-23. American Thoracic Society.

4. Lötvall J, Akdis CA, Bacharier LB, Bjermer L, Casale TB, Custovic A, et al. Asthma endotypes: a new approach to classification of disease entities within the asthma syndrome. J Allergy Clin Immunol. 2011;127:355-60 Available from: http://www.sciencedirect.com/science/article/pii/S009167491 0018580.

5. Wenzel SE. Asthma phenotypes: the evolution from clinical to molecular approaches. Nat Med. Nature Publishing Group, a division of Macmillan Publishers Limited. All Rights Reserved. 2012;18:716-25. https://doi.org/10.1 038/nm.2678.

6. Wenzel S. Severe asthma: from characteristics to phenotypes to endotypes. Clin Exp Allergy. 2012;42:650-8.

7. Custovic A, Henderson J, Simpson A. Does understanding endotypes translate to better asthma management options for all? J Allergy Clin Immunol. 2019;144:25-33. Elsevier.

8. Nunes C, Pereira AM, Morais-Almeida M. Asthma costs and social impact. Asthma Res Pract. 2017;3:1.
9. Esteban-Gorgojo I, Antolín-Amérigo D, Domínguez-Ortega J, Quirce S. Noneosinophilic asthma: current perspectives. J Asthma Allergy. 2018;11:267. Dove Press.

10. Kuruvilla ME, Lee FE-H, Lee GB. Understanding asthma phenotypes, endotypes, and mechanisms of disease. Clin Rev Allergy Immunol Springer. 2019:56:219-33.

11. Guibas G V, Mathioudakis AG, Tsoumani M, Tsabouri S. Relationship of allergy with asthma: there are more than the allergy "Eggs" in the asthma "Basket" [Internet]. Front Pediatr. 2017:92. Available from: https://www. frontiersin.org/article/10.3389/fped.2017.00092.

12. Zwaigenbaum L, Bryson S, Lord C, Rogers S, Carter A, Carver L, et al. No Title. In: Australian Government, editor. Env Heal Perspect [Internet]. 1995/ 03/01. Copenhagen: Blackwell Publishing Ltd; 2013;17:n/a-n/a. Available from: http://www.biomedcentral.com/1471-2431/13/124/prepub.

13. Chung KF. Asthma phenotyping: a necessity for improved therapeutic precision and new targeted therapies. J Intern Med. 2016;279:192-204. Wiley Online Library.

14. Agache IO. From phenotypes to endotypes to asthma treatment. Curr Opin Allergy Clin Immunol. 2013;13:249-56.

15. McConnell R, Berhane K, Yao L, Jerrett M, Lurmann F, Gilliland F, et al. Traffic susceptibility, and childhood asthma. Environ Health Perspect National Institute of Environmental Health Sciences. 2006;114:766-72.

16. Fang Z, Huang C, Zhang J, Xie J, Dai S, Ge E, et al. Traffic-related air pollution induces non-allergic eosinophilic airway inflammation and cough hypersensitivity in Guinea-pigs. Clin Exp Allergy. 2019;49:366-77. Wiley Online Library.

17. Honkova K, Rossnerova A, Pavlikova J, Svecova V, Klema J, Topinka J, et al. Gene expression profiling in healthy newborns from diverse localities of the Czech Republic. Environ Mol Mutagen. 2018;59:401-15.

18. Choi H, Dostal M, Pastorkova A, Rossner P Jr, Sram RJ, Ho S-M. Greater susceptibility of girls to airborne Benzo [a] pyrene for obesity-associated childhood asthma. Environ Int. Elsevier. 2018;121:308-16.

19. Choi H, Song W, Wang M, Sram RJ, Zhang B. Benzo[a]pyrene is associated with dysregulated myelo-lymphoid hematopoiesis in asthmatic children. Environ Int. 2019;128:218-32 Available from: http://www.sciencedirect.com/ science/article/pii/S0160412018317215. Elsevier.

20. Fernández D, Sram RJ, Dostal M, Pastorkova A, Gmuender $H$, Choi $H$. Modeling unobserved heterogeneity in susceptibility to ambient benzo[a]pyrene concentration among children with allergic asthma using an unsupervised learning algorithm. Int J Environ Res Public Health. 2018:15:106.

21. Rossnerova A, Spatova M, Rossner P, Solansky I, Sram RJ. The impact of air pollution on the levels of micronuclei measured by automated image analysis. Mutat res. 2009;669:42-7 Available from: http://www.ncbi.nlm.nih gov/pubmed/19409399. 2009/05/05.

22. Ambroz A, Vlkova $V$, Rossner $P$, Rossnerova A, Svecova $V$, Milcova $A$, et al. Impact of air pollution on oxidative DNA damage and lipid peroxidation in mothers and their newborns. Int J Hyg Env Heal. 2016;219:545-56.

23. Choi H, Tabashidze N, Rossner P, Dostal M, Pastorkova A, Kong SW, et al. Altered vulnerability to asthma at various levels of ambient Benzo[a]Pyrene by CTLA4, STAT4 and CYP2E1 polymorphisms. Environ Pollut. 2017;231: 1134-44. Elsevier.

24. Sram RJ, Binkova B, Dostal M, Merkerova-Dostalova M, Libalova H, Milcova A et al. Health impact of air pollution to children. Int J Hyg Environ Health Elsevier. 2013;216:533-40

25. Choi $\mathrm{H}$, Harrison $\mathrm{R}$, Komulainen $\mathrm{H}$, Saborit JMD. Polycyclic aromatic hydrocarbons. WHO Guidel indoor air Qual Sel Pollut. World Health Organization; 2010.

26. Pinto JP, Stevens RK, Willis RD, Kellogg R, Mamane Y, Novak J, et al. Czech air quality monitoring and receptor modeling study. Environ Sci Technol. 1998:32:843-54.

27. Ghosh R, Rossner P, Honkova K, Dostal M, Sram RJ, Hertz-Picciotto I. Air pollution and childhood bronchitis: interaction with xenobiotic, immune regulatory and DNA repair genes. Environ Int. 2016;87:94-100. Elsevier.

28. Hertz-Picciotto I, Baker RJ, Yap P-S, Dostál M, Joad JP, Lipsett M, et al. Early childhood lower respiratory illness and air pollution. Environ Health Perspect. National Institute of Environmental Health Science. 2007;115:1510.

29. Rossner P Jr, Rossnerova A, Spatova M, Beskid O, Uhlirova K, Libalova H, et al. Analysis of biomarkers in a Czech population exposed to heavy air pollution. Part II: chromosomal aberrations and oxidative stress. Mutagenesis. 2012;28:97-106. Oxford University Press UK. 
30. Rossner P, Svecova V, Schmuczerova J, Milcova A, Tabashidze N, Topinka J, et al. Analysis of biomarkers in a Czech population exposed to heavy air pollution. Part I: bulky DNA adducts. Mutagenesis. 2013;28:89-95 Available from: http://mutage.oxfordjournals.org/content/28/1/89.abstract.

31. Levy ML, Quanjer PH, Rachel B, Cooper BG, Holmes S, Small IR. Diagnostic Spirometry in Primary Care: Proposed standards for general practice compliant with American Thoracic Society and European Respiratory Society recommendations. Prim Care Respir J. 2009;18:130-47. Nature Publishing Group.

32. Butler AR. The Jaffé reaction. Identification of the coloured species. Clin Chim Acta. 1975:59:227-32.

33. Rossnerova A, Spatova M, Rossner P, Novakova Z, Solansky I, Sram RJ. Factors affecting the frequency of micronuclei in asthmatic and healthy children from Ostrava. Mutat Res Mol Mech Mutagen. 2011;708:44-9. Elsevier.

34. Dostál M, Milcová A, Binková B, Kotěšovec F, Nožička J, Topinka J, et al. Environmental tobacco smoke exposure in children in two districts of the Czech Republic. Int J Hyg Env Heal. 2008;211:318-25.

35. Ghosh R, Topinka J, Joad JP, Dostal M, Sram RJ, Hertz-Picciotto I. Air pollutants, genes and early childhood acute bronchitis. Mutat Res Mol Mech Mutagen. 2013;749:80-6.

36. Cole TJ, Bellizzi MC, Flegal KM, Dietz WH. Establishing a standard definition for child overweight and obesity worldwide: international survey. Bmj. 2000; 320:1240. British Medical Journal Publishing Group.

37. de Nijs SB, Venekamp LN, Bel EH. Adult-onset asthma: is it really different? Eur Respir Rev Eur Respiratory Soc. 2013;22:44-52.

38. Li N, Buglak N. Convergence of air pollutant-induced redox-sensitive signals in the dendritic cells contributes to asthma pathogenesis. Toxicol Lett [Internet]. 2015;237:55-60 Available from: http://www.sciencedirect.com/ science/article/pii/S0378427415001848.

39. Li N, Sioutas C, Cho A, Schmitz D, Misra C, Sempf J, et al. Ultrafine particulate pollutants induce oxidative stress and mitochondrial damage. Env Heal Perspect. 2003;111:455-60.

40. Papadopoulos NG, Arakawa H, Carlsen K, Custovic A, Gern J, Lemanske R, et al. International consensus on (ICON) pediatric asthma. Allergy. 2012;67: 976-97. Wiley Online Library.

41. Leone N, Courbon D, Thomas F, Bean K, Jégo B, Leynaert B, et al. Lung function impairment and metabolic syndrome: the critical role of abdominal obesity. Am J Respir Crit Care Med. 2009;179:509-16. American Thoracic Society

42. Guarnieri M, Balmes JR. Outdoor air pollution and asthma. Lancet. 2014;383: 1581-92 Available from: http://www.ncbi.nlm.nih.gov/pubmed/24792855.

43. Baldacci S, Maio S, Cerrai S, Sarno G, Baïz N, Simoni M, et al. Allergy and asthma: effects of the exposure to particulate matter and biological allergens. Respir Med Elsevier. 2015;109:1089-104.

44. Manners S, Alam R, Schwartz DA, Gorska MM. A mouse model links asthma susceptibility to prenatal exposure to diesel exhaust. J Allergy Clin Immunol. 2014;134:63-72 e7.

45. Perzanowski MS, Chew GL, Divjan A, Jung KH, Ridder R, Tang D, et al. Earlylife cockroach allergen and polycyclic aromatic hydrocarbon exposures predict cockroach sensitization among inner-city children. J Allergy Clin Immunol. 2013;131:886-93 e6.

46. Hew KM, Walker Al, Kohli A, Garcia M, Syed A, McDonald-Hyman C, et al. Childhood exposure to ambient polycyclic aromatic hydrocarbons is linked to epigenetic modifications and impaired systemic immunity in T cells. Clin Exp Allergy. 2015;45:238-48 Available from: http://www.ncbi.nlm.nih.gov/ pubmed/25048800.

47. Li N, Georas S, Alexis N, Fritz P, Xia T, Williams MA, et al. A work group report on ultrafine particles (American Academy of Allergy, Asthma \& Immunology): why ambient ultrafine and engineered nanoparticles should receive special attention for possible adverse health outcomes in human subjects. J Allergy Clin Immunol Elsevier. 2016;138:386-96.

48. Binkova B, Topinka J, Sram RJ, Sevastyanova O, Novakova Z, Schmuczerova $J$, et al. In vitro genotoxicity of PAH mixtures and organic extract from urban air particles part I: acellular assay. Mutat Res [Internet]. 2007;620:11422 Available from: http://www.ncbi.nlm.nih.gov/entrez/query.fcgi?cmd= Retrieve\&db=PubMed\&dopt=Citation\&list_uids $=17442348$.

49. van Grevenynghe J, Bernard M, Langouet S, Le Berre C, Fest T, Fardel O. Human CD34-positive hematopoietic stem cells constitute targets for carcinogenic polycyclic aromatic hydrocarbons. J Pharmacol Exp Ther. 2005; 314:693-702 Available from: http://www.ncbi.nlm.nih.gov/pubmed/1 5860575. 2005/04/30.
50. Choi H, Spengler J. Source attribution of personal exposure to airborne polycyclic aromatic hydrocarbon mixture using concurrent personal, indoor, and outdoor measurements. Environ Int. 2014;63:173-81.

51. Choi H, Melly S, Spengler J. Intraurban and longitudinal variability of classical pollutants in Kraków, Poland, 2000-2010. Int J Environ Res Public Health. 2015;12:4967-91.

52. Choi H, Zdeb M, Perera F, Spengler J. Estimation of chronic personal exposure to airborne polycyclic aromatic hydrocarbons. Sci Total Environ. 2015:527-528:252-61.

53. Choi H, Wang L, Lin X, Spengler JD, Perera FP. Fetal window of vulnerability to airborne polycyclic aromatic hydrocarbons on proportional intrauterine growth restriction. PLoS One. 2012;7.

54. Pulkrabova J, Stupak M, Svarcova A, Rossner P, Rossnerova A, Ambroz A, et al. Relationship between atmospheric pollution in the residential area and concentrations of polycyclic aromatic hydrocarbons (PAHs) in human breast milk. Sci Total Environ. 2016;562:640-7. Elsevier.

\section{Publisher's Note}

Springer Nature remains neutral with regard to jurisdictional claims in published maps and institutional affiliations.

\section{Ready to submit your research? Choose BMC and benefit from:}

- fast, convenient online submission

- thorough peer review by experienced researchers in your field

- rapid publication on acceptance

- support for research data, including large and complex data types

- gold Open Access which fosters wider collaboration and increased citations

- maximum visibility for your research: over $100 \mathrm{M}$ website views per year

At BMC, research is always in progress.

Learn more biomedcentral.com/submissions 